\title{
PENGARUH AUDIT TENURE DAN AUDIT SPESIALIS TERHADAP KUALITAS AUDIT PADA PERUSAHAAN MANUFAKTUR YANG TERDAFTAR DI BURSA EFEK INDONESIA TAHUN 2016-2018
}

\author{
BADEWIN ${ }^{1}$ \\ Universitas Islam Indragiri Tembilahan \\ Email: win.badewin@gmail.com \\ SITI HUJAIMAH ${ }^{2}$ \\ Universitas Islam Indragiri Tembilahan
}

\begin{abstract}
This study aims to empirically examine the effect of audit tenure and specialist auditors on audit quality in manufacturing companies listed on the Indonesia Stock Exchange in 2016-2018. The sample selection uses a purposive sampling method. The research sample is manufacturing companies listed on the Indonesia Stock Exchange in 2016-2018 as many as 37 companies with the total data processed for 3 years as many as 111 companies. The type of data used is secondary data obtained from the official website www.idx.co.id in the form of a company's financial statements. The data analysis tool used is logistic regression with the help of SPSS version 26 for windows. The results showed that the audit tenure variable has a regression coefficient of 0.320 above $5 \%$ significance so it can be concluded that the audit tenure has no effect on audit quality, while the specialist auditor variable has a regression coefficient of 0,000 under significant $5 \%$, so it can be concluded that the specialist auditor affect the quality of the audit.
\end{abstract}

Keywords: Audit Tenure, Specialist Audit and Audit Quality.

\section{ABSTRAK}

Penelitian ini bertujuan untuk menguji secara empiris pengaruh audit tenure dan auditor spesialis terhadap kualitas audit pada perusahaan manufaktur yang terdaftar di Bursa Efek Indonesia tahun 2016-2018. Pemilihan sampel menggunakan metode purposive sampling. Sampel penelitian yaitu perusahaan manufaktur yang terdaftar di Bursa Efek Indonesia tahun 2016-2018 sebanyak 37 perusahaan dengan jumlah data yang diolah selama 3 tahun sebanyak 111 perusahaan. Jenis data yang digunakan adalah data skunder yang diperoleh dari website resmi www.idx.co.id berupa laporan keuangan perusahaan. Alat analisa data yang digunakan adalah regresi logistik dengan bantuan program SPSS versi 26 for windows. Hasil penelitian menunjukan bahwa variabel audit tenure memiliki nilai koefesien regresi sebesar 0,320 diatas signifikan 5\% sehingga dapat disimpulkan bahwa audit tenure tidak berpengaruh terhadap kualitas audit, sedangkan Variabel auditor spesialis memiliki nilai koefisien regresi sebesar 0,000 dibawah signifikan 5\%, sehingga dapat disimpulkan bahwa auditor spesialis berpengaruh terhadap kualitas audit.

\section{Kata Kunci : Audit Tenure, Audit Spesialis dan Kualitas Audit}

\section{PENDAHULUAN}

\subsection{Latar Belakang}

Daya tarik investor untuk menanamkan modal di perusahaan yaitu dengan meningkatkan kinerja perusahaan yang dapat dilihat dari laporan keuangan. Kinerja keuangan merupakan hal yang sangat penting bagi perusahaan sebagai elemen yang menjadi tanggungjawab dewan direksi, termasuk aktifitas diperusahaan. Hal tersebut menunjukan bahwa perusahaan pasti memerlukan jasa akuntan publik (auditor) untuk memeriksa laporan keuangan perusahaan. Pemeriksaan tersebut tidak dimaksudkan untuk mencari kesalahan atau kecurangan, walaupun pada dasarnya saat proses audit, kesalahan dan kecurangan sangat memungkinkan untuk ditemukan. Hal ini tentunya mengharapkan audit yang dihasilkan adalah audit yang berkualitas untuk membantu dalam pengambilan keputusan ekonomi bagi perusahaan dan pihak terkait (Farida, 2016).

Audit tenure dapat memberikan dampak pada perusahaan klien, misalnya independensi dan kompetensi auditor, hubungan emosional antara auditor dan klien, fee, dan lain sebagainya. Peraturan mengenai perikatan kerja audit ini diatur di Indonesia melalui Peraturan Menteri Keuangan No. 17/PMK.01/2008 dimana masa pemberian jasa bagi akuntan publik, sebelumnya KAP dapat memberikan jasa audit umum paling lama untuk 5 (lima) tahun buku berturut-turut kemudian dirubah menjadi 6 (enam) tahun buku berturut-turut dan untuk seorang Akuntan Publik paling lama untuk 3 (tiga) tahun buku berturut-turut.

Auditor spesialis memiliki pengetahuan dan pemahaman yang lebih akan bidang industri klien jika dibandingkan dengan auditor non spesialis. Pengetahuan auditor akan bidang tertentu ini pula dapat meningkatkan kualitas hasil audit yang dilakukannya, hal ini dikarenakan auditor spesialis akan lebih gampang untuk mendeteksi kekeliruan dan penyimpangan yang terjadi pada pelaporan keuangan klien. Auditor spesialis menyandang pengetahuan dan pemahaman yang lebih baik mengenai karakteristik bisnis klien dibandingkan dengan auditor non spesialis. Auditor spesialis juga lebih memungkinkan untuk mendeteksi kekeliruan dan penyimpangan yang terjadi pada laporan keuangan, sehinggga dapat memudahkan perusahaan dalam menyediakan informasi laba yang lebih baik. Manajer dan senior audit spesialis akan lebih 
baik dalam mengetahui terjadinya kesalahan jika mereka diberikan tugas audit sesuai dengan spesialisasi mereka (Panjaitan, 2014).

Audit merupakan proses untuk memperoleh dan mengevaluasi bukti secara objektif mengenai pernyataan tentang kegiatan dan kejadian ekonomi, dengan tujuan untuk mendapatkan tingkat kesesuaian antara pernyataan tersebut dengan kriteria yang telah ditetapkan, serta penyampaian hasilnya kepada pemakai. Kualitas audit merupakan kemampuan seorang auditor yang menilai dan memberikan opini yang tepat sesuai dengan keadaan perusahaan sesungguhnya sehingga para pemakai informasi dapat tepat dalam pengambilan keputusan. Seorang auditor menjalankan pekerjaan harus bertindak secara eksklusif sebagai seorang auditor yang mempunyai tanggung jawab kepada klien, masyarakat, kolage dan diri sendiri sendiri serta dalam memenuhi tanggungjawab profesi, akuntansi mengatur prilakunya berdasarkan kode etik yang mempunyai prinsip fundamental.

Penelitian Maharani (2014) menunjukan hasil bahwa variabel audit tenure tidak berpengaruh terhadap kualitas audit, sedangkan variabel audit fee dan rotasi audit berpengaruh terhadap kualitas audit. Variabel spesialis auditor menunjukan hasil tidak berpengaruh terhadap kualitas audit. Hal ini disebabkan karena kualitas audit yang dihasilkan oleh KAP The Big 4 spesialis, dan KAP The Big 4 non spesialis adalah sama.

Penelitian ini mereview penelitian dari Maharani (2014) dengan perbedaan penelitian terletak pada priode pengamatan, variabel penelitian dan objek penelitian. Penelitian sebelumnya menggunakan variabel independen audit tenure, audit fee, rotasi audit dan spesialis auditor. Sedangkan penelitian ini menggunakan variabel audit tenure dan auditor spesialis. Objek penelitian dalam penelitian ini adalah perusahaan manufaktur yang terdaftar di Bursa Efek Indonesia (BEI) priode 2016-2018.

Peneliti memilih perusahaan manufaktur yang terdaftar Bursa Efek Indonesia (BEI) tahun 2016 sampai dengan 2018 karena terjadi fenomena pada perusahaan yang telah kehabisan cara dalam mempertahankan kinerja keuangannya. Penggelembungan laba sebesar 1,22 milyar dolar AS yang awalnya ingin menciptakan investor confidence malah mencoreng nama besar perusahaan Toshiba selama ini. Dari kejadian tersebut dimana orang-orang hidup dalam masyarakat merasa tidak aman, tenang dan nyaman hanya karena perusahaan Toshiba telah gagal dalam menjalankan prinsip kebenaran dan tanggungjawab.

Berdasarkan penjelasan di atas, peneliti tertarik melakukan penelitian dengan judul Pengaruh Audit

Tenure Dan Audit Spesialis Terhadap Kualitas Audit pada Perusahaan Manufaktur yang Terdaftar di Bursa Efek Indonesia Tahun 2016-2018.

\subsection{Perumusan masalah}

Berdasarkan latar belakang yang telah dikemukakan diatas, maka perumusan masalah dalam penelitian ini adalah sebagai berikut:

1. Apakah audit tenure berpengaruh terhadap kualitas audit pada perusahaan manufaktur yang terdaftar di Bursa Efek Indonesia?

2. Apakah auditor spesialis berpengaruh terhadap kualitas audit pada perusahaan manufaktur yang terdaftar di Bursa Efek Indonesia?

3. Apakah audit tenure dan auditor spesialis berpengaruh secara simultan terhadap kualitas audit pada perusahaan manufaktur yang terdaftar Bursa Efek Indonesia?

\section{TINJUAN PUSTAKA}

\subsection{Auditing}

Auditing adalah pengumpulan dan mengevaluasi (secara objektif) bukti yang berhubungan dengan asersi tentang tindakan-tidakan dan kejadian ekonomi, dalam rangka menentukan tingkat kepatuhan antara asersi dengan kriteria yang telah ditetapkan serta mengkomunikasikan hasilnya kepada pihak-pihak yang berkepentingan. Auditing adalah pengumpulan serta pengevaluasian bukti atas informasi untuk menentukan tingkat kesesuaian informasi dengan kriteria yang telah ditetapkan. Auditing harus dilaksanakan oleh seseorang yang kompeten dan independen (Arens et al, 2008).

Laporan audit merupakan media yang dipakai oleh auditor dalam berkomunikasi dengan pihak internal dan eksternal dan mengambil keputusan yang tepat. Dalam laporan tersebut auditor menyatakan pendapatnya mengenai kewajaran laporan keuangan yang disajikan dalam suatu laporan tertulis berupa laporan audit baku.

\subsection{Standar Auditing}

Standar auditing yang dilaksanakan auditor telah ditetapkan IAI. Standar audit ini merupakan pedoman umum untuk membantu auditor dalam memenuhi tanggung jawab profesionalnya sehubungan dengan audit yang dilakukan atas laporan keuangan historis klienya. Standar ini mencakup pertimbangan mengenai kualitas professional seperti kompetensi dan independensi, persyaratan pelaporan dan bahan bukti audit (Hery, 2017).

Standar auditing yang telah ditetapkan dan disahkan oleh Ikatan Akuntan Indonesia (IAI) (Henry, 2017) adalah sebagai berikut: 
1. Standar Umum

a. Audit harus dilaksanakan oleh seseorang atau lebih yang memiliki keahlian dan pelatihan teknis yang cukup sebagai auditor.

b. Dalam semua hal yang berhubungan dengan perikatan independensi dalam sikap mental harus dipertahankan oleh auditor.

c. Dalam pelaksanaan audit dan penyusunan laporannya. Auditor wajib menggunakan kemahiran profesionalnya dengan cermat dan seksama.

2. Standar Pekerjaan Lapangan

a. Pekerjaan harus direncanakan sebaik-baiknya dan jika menggunakan asisten harus disupervisi dengan semestinya.

b. Pemahaman memadai atas pengendalian intern harus diperoleh untuk merencanakan audit dan menentukan sifat. Saat dan lingkup pengujian yang akan dilakukan.

c. Bukti audit yang cukup harus diperoleh melalui inspeksi, pengamatan, permintaan keterangan, dan konfirmasi sebagai dasar memadai untuk menyatakan pendapat atas laporan keuangan yang diaudit.

3. Standar Pelaporan

a. Laporan auditor harus menyatakan apakah laporan keuangan telah disusun sesuai dengan prinsip akuntansi yang berlaku umum di Indonesia.

b. Laporan auditor harus menunjukkan atau menyatakan jika ada ketidak konsistenan penerapan prinsip akuntansi dalam penyusunan laporan keuangan periode berjalan dibandingkan dengan penerapan prinsip akuntansi tersebut dalam periode sebelumnya.

c. Pengungkapan informatif dalam laporan keuangan harus dipandang memadai, kecuali dinyatakan lain dalam laporan auditor.

d. Laporan auditor harus memuat suatu pernyataan pendapat mengenai laporan keuangan secara keseluruhan atau suatu asersi bahwa pernyataan demikian tidak dapat diberikan. Jika pendapat secara keseluruhan tidak dapat diberikan, maka alasannya harus dinyatakan, dalam hal nama auditor dikaitkan dengan laporan keuangan, maka laporan auditor harus memuat petunjuk yang jelas mengenai sifat pekerjaan audit yang dilaksanakanJika ada, dan tingkat tanggungjawab yang dipikul oleh auditor.

\subsection{Opini Audit}

Opini audit adalah pendapat diberikan tentang kewajaran penyajian laporan keuangan. Laporan audit bentuk baku dalam Seksi No. 508 paragraf 07 dimana laporan audit bentuk baku memuat suatu pernyataan bahwa laporan keuangan menyajikan secara wajar, dalam semua hal yang material, posisi keuangan suatu satuan usaha, hasil usaha dan arus kas sesuai dengan prinsip akuntansi yang berlaku umum. Pendapat ini dijelaskan dalam laporan audit pada paragraf ketiga (Mulyadi, 2014) yaitu sebagai berikut:

1. Pendapatan Wajar tanpa pengecualian (Unqualified Opinion).

2. Laporan Wajar tanpa pengecualian dengan bahasa penjelasan (Unqualified opinion Report With Ekplanatory Langunge).

3. Pendapat Wajar Dengan Pengecualian (Qualified Opinion).

4. Pendapat Tidak Wajar (Advance Opinin).

5. Pernyataan Tidak Memberikan Pendapat (Disclamer opinion).

\subsection{Kualitas Audit}

Tujuan menyeluruh dari audit laporan keuangan adalah untuk menyatakan pendapat apakah keuangan klien kita tersaji secara wajar dalam semua hal yang material sesuai prinsip-prinsip yang berlaku (Kurniasih \& Rohman, 2014). Kualitas audit adalah proses sistematik untuk memperoleh dan mengevaluasi bukti secara objektif mengenai pernyataan-pernyataan tentang kegiatan dan kejadian ekonomi, dengan tujuan untuk menetapkan tingkat kesesuaian antara pernyataan-pernyataan tersebut dengan kiteria yang telah ditetapkan, serta penyampaian hasil-hasil kepada pemakai yang berkepentingan (Mulyadi, 2014).

\subsection{Audit Tenure}

Secara umum, audit merupakan suatu kegiatan pemeriksaan yang dilakukan secara kritis dan sistematis oleh seseorang yang independen untuk memperoleh dan mengevaluasi bukti-bukti secara objektif mengenai pernyataan-pernyataan kegiatan dan kejadian ekonomi. Audit tenure adalah hubungan masa perikatan audit antara KAP dan klien terkait jasa audit yang telah disepakati sebelumnya yang diukur dengan jumlah tahun (Junaidi dan Hartono, 2010).

\subsection{Auditor Spesialis}

Auditor spesialis menggambarkan keahlian dan pengalaman audit seorang auditor pada bidang industri tertentu dan menyatakan bahwa auditor spesialis merupakan dari dimensi kualitas audit, karena pengalaman dan kemampuan auditor tentang industri merupakan salah satu dari elemen dari keahlian auditor. Pengalaman yang dimiliki auditor dalam melaksanakan audit perusahaan yang sama membuat auditor tersebut memiliki spesialis. Auditor yang terspesialisasi mempunyai pengalaman audit perusahaan yang sama sebelumnya dan lebih memahami kondisi perusahaan (Pramaswaradana, 2017). 


\subsection{Kerangka pemikiran}

Adapun kerangka yang menjadi dasar dalam penelitian ini adalah sebagai berikut :

Gambar 2.1

Kerangka Pemikiran

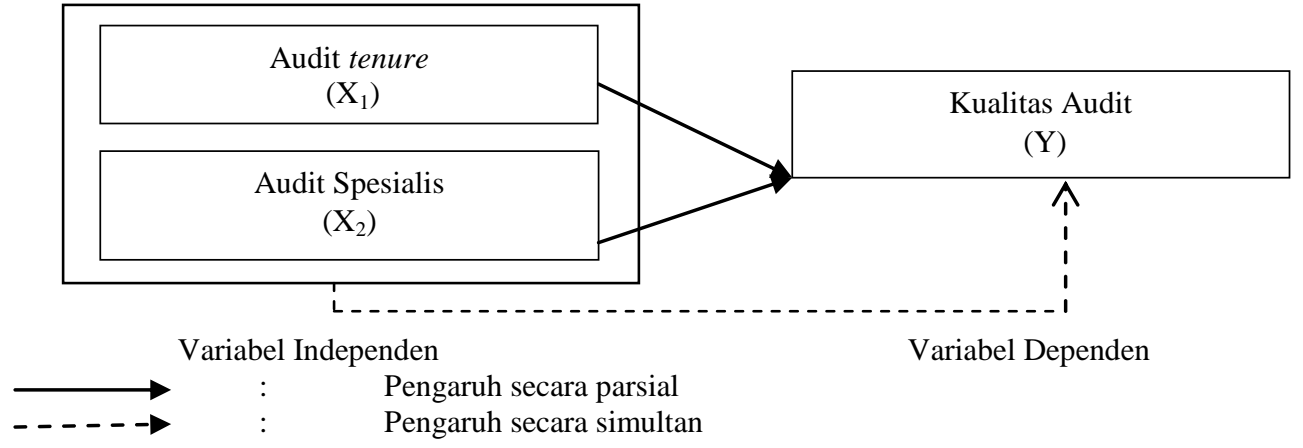

\subsection{Hipotesa}

$\mathrm{H}_{1}$ : Audit tenure berpengaruh terhadap kualitas audit pada perusahaan manufaktur yang terdaftar di Bursa Efek Indonesia tahun 2016-2018.

$\mathrm{H}_{2}$ : Auditor spesialis berpengaruh terhadap kualitas audit pada perusahaan manufaktur yang terdaftar di Bursa Efek Indonesia tahun 2016-2018.

$\mathrm{H}_{3}$ : Audit tenure dan auditor spesialis berpengaruh terhadap kualitas auditpada perusahaan manufaktur yang terdaftar di Bursa Efek Indonesia tahun 2016-2018.

\section{METODE PENELITIAN}

\subsection{Tempat Dan Waktu Penelitian}

Penelitian ini dilakukan pada perusahaan manufaktur yang terdaftar di Bursa Efek Indonesia (BEI), melalui situs Resmi Bursa Efek Indonesia yaitu www.idx.co.id. Data tersebut berupa time series dalam suatu periode 31 Desember yaitu dari tahun 2016-2018 dengan lama waktu penelitian selama 2 bulan yaitu dari bulan Februari sampai bulan Maret 2020.

\subsection{Populasi Dan Sampel}

Populasi adalah sekelompok orang atau kejadian atau segala sesuatu yang mempunyai karakteristik tertentu. Anggota populasi disebut dengan elemen populasi. Populasi dalam penelitian ini adalah perusahaan manufaktur yang terdaftar di Bursa Efek Indonesia (BEI) (Indriantoro dan Supomo, 2016).

Sampel adalah sebagian dari elemen-elemen populasi. Perusahaan yang dijadikan sampel dalam penelitian ini adalah perusahaan manufaktur yang terdaftar di Bursa Efek Indonesia (BEI), dimana teknik penentuan sampel dalam penelitian ini menggunakan metode purposive sampling. Purposive sampling adalah teknik pengambilan sampel secara tidak acak dan informasinya diperoleh dengan pertimbangan tertentu (Indriantoro dan Supomo, 2016).

Adapun kriteria perusahaan yang dijadikan sampel dalam penelitian ini adalah sebagai berikut :

1. Perusahaan manufaktur yang terdaftar di Bursa Efek Indonesia selama tahun 2016, 2017, 2018.

2. Perusahaan manufaktur yang tidak memiliki ekuitas positif selama priode 2016, 2017, 2018.

3. Perusahaan manufaktur yang tidak mengalami delisting dari Bursa Efek Indonesia selama priode pengamatan 2016, 2017, 2018.

4. Perusahaan manufaktur yang tidak menyajikan Laporan keuangan dengan menggunakan mata uang rupiah $(\mathrm{Rp})$.

\subsection{Prosedur Pengumpulan Data}

Metode pengumpulan data menggunakan metode dokumentasi, metode dokumentasi dilakukan dengan cara penyalinan dan pengarsipan data-data dari sumber-sumber yang tersedia yaitu data sekunder. Data sekunder merupakan data penelitian yang diperoleh peneliti secara tidak langsung melalui media perantara (diperoleh dan dicatat pihak lain). Data penelitian ini diperoleh melalui situs BEI yakni $w w w . i d x . c o . i d$ yaitu berupa laporan keuangan perusahaan. Data tersebut berupa time series dalam periode per 31 Desember yaitu tahun 2016-2018. Data sekunder lainnya yang digunakan dalam penelitian ini berupa jurnal, artikel, dan lainnya yang berkaitan dengan penelitian.

\subsection{Teknik Analisa}

Analisis data dalam penelitian ini menggunakan analisis regresi logistik karena variabel terikatnya yaitu kualitas audit yang merupakan data kualitatif dengan variabel dummy dan variabel bebasnya merupakan kombinasi antara variabel metric dan non metric. Regresi logistik digunakan untuk menguji apakah probabilitas terjadinya variabael terikat dapat diprediksi dengan variabel bebasnya (Ghozali, 2011). 


\section{HASIL PENELITIAN DAN PEMBAHASAN}

\subsection{Gambaran Umum Objek Penelitian}

Perusahaan manufaktur adalah perusahaan yang bergerak dibidang pengolahan menjadi barang jadi siap pakai. Perusahaan manufaktur saat ini berkembang sangat pesat setiap tahunnya baik dari segi laporan keuangan maupun saham yang telah go public. Prospek bisnis dibidang manufaktur juga sangat menguntungkan setiap tahunnya yang nantinya akan menarik para investor untuk menanamkan modalnya disektor ini dimasa yang akan datang. Sebuah perusahaan induk dikatakan perusahaan manufaktur apabila ada tahapan input dan proses output yang akhirnya menghasilkan suatu produk.

Dalam penelitian ini, jumlah perusahaan manufaktur yang terdaftar di Bursa Efek Indonesia (BEI) priode 2016 sampai 2018 adalah sebanyak 111 perusahaan. Berikut proses pemilihan sampel yang sesuai dengan kriteria sampel yaiut sebagai berikut:

Tabel 4.1

Proses Pemilihan Sampel

\begin{tabular}{|c|l|c|}
\hline No. & \multicolumn{1}{|c|}{ Keterangan } & Jumlah \\
\hline 1 & $\begin{array}{l}\text { Perusahaan manufaktur yang terdaftar di Bursa Efek Indonesia selama tahun } \\
2016,2017,2018 .\end{array}$ & 138 \\
\hline 2 & \begin{tabular}{l} 
Perusahaan manufaktur yang tidak memiliki ekuitas positif. \\
Indonesia selama priode pengamatan 2016, 2017, 2018. \\
\hline 3
\end{tabular} $\begin{array}{l}\text { Perusahaan manufaktur yang tidak mengalami delisting dari Bursa Efek } \\
\text { Perusahaan manufaktur yang tidak menyajikan Laporan keuangan dengan } \\
\text { menggunakan mata uang rupiah (Rp) }\end{array}$ & 22 \\
\hline Jumlah Perusahaan Sampel & 37 \\
\hline Jumlah Tahun Pengamatan & 3 \\
\hline Total Sampel Penelitian & 111 \\
\hline
\end{tabular}

(Sumber : Data Olahan, 2020)

Berikut disajikan daftar perusahaan yang dijadikan sampel dalam penelitian ini sebagai berikut :

Tabel 4.2

Daftar Perusahaan Sampel

\begin{tabular}{|c|c|c|}
\hline NO & KODE SAHAM & NAMA PERUSAHAAN \\
\hline 1 & AKPI & ArghaKarya Prim \\
\hline 2 & ALKA & AlakasaIndustrindo \\
\hline 3 & AMFG & Asahimas Flat Glass \\
\hline 4 & ASII & Astra International \\
\hline 5 & AUTO & Astra Autoparts \\
\hline 6 & BATA & Sepatu Bata \\
\hline 7 & BTON & BetonjayaManunggal \\
\hline 8 & BUDI & PT Budi Starch \& Sweetener \\
\hline 9 & CPIN & Charoen Pokphand Indonesia \\
\hline 10 & DLTA & Delta Djakarta \\
\hline 11 & DVLA & Darya VariaLaboratoria \\
\hline 12 & EKAD & Ekadharma International \\
\hline 13 & GGRM & GudangGaram \\
\hline 14 & ICBP & Indofood CBP SuksesMakmur \\
\hline 15 & INCI & Intanwijaya International \\
\hline 16 & INDF & Indofood SuksesMakmur \\
\hline 17 & INDS & Indospring \\
\hline 18 & JPFA & JapfaComfeed Indonesia \\
\hline 19 & KBLM & KabelindoMurni \\
\hline 20 & KDSI & KedawungSetia Industrial \\
\hline 21 & KICI & KedaungIndan Can \\
\hline 22 & KLBF & Kalbe Farma \\
\hline 23 & LION & Lion Metal Works \\
\hline 24 & MAIN & MalindoFeedmill \\
\hline 25 & $\mathrm{PICO}$ & Pelangi Indah Canindo \\
\hline 26 & ROTI & Nippon IndosariCorpindo \\
\hline 27 & SCCO & Supreme Cable Manufacturing \\
\hline 28 & SMGR & Semen Indonesia \\
\hline 29 & SMSM & SelamatSempurna \\
\hline 30 & SRSN & Indo Acitama \\
\hline 31 & TCID & Mandom Indonesia \\
\hline 32 & TOTO & Surya Toto Indonesia \\
\hline 33 & TRST & TriasSentosa \\
\hline 34 & TSPC & Tempo Scan Pasific \\
\hline 35 & ULTJ & Ultajaya Milk Industri \\
\hline 36 & UNVR & Uniliver Indonesia \\
\hline 37 & WIIM & WismilakIntiMakmur \\
\hline
\end{tabular}

(Sumber Data Olahan, 2020) 


\subsection{Hasil Penelitian}

\subsubsection{Uji Statistik Deskriptif}

Uji statistik deskriptif digunakan untuk menggambarkan statistik data mengenai variabel yang diteliti. Hasil pengujian statistik deskriptif ini mencakup nilai rata-rata (mean), nilai minimum dan nilai maksimum, dan standar deviasi berdasarkan data dan variabel-variabel yang teliti. Hal ini perlu dilakukan untuk melihat gambaran keseluruhan dari sampel yang berhasil dikumpulkan dan memenuhi syarat untuk dijadikan penelitian tanpa bermaksud membuat kesimpulan yang berlaku umum atau generalisasi.

Tabel 4.3

Hasil uji statistik deskriptif

Descriptive Statistics

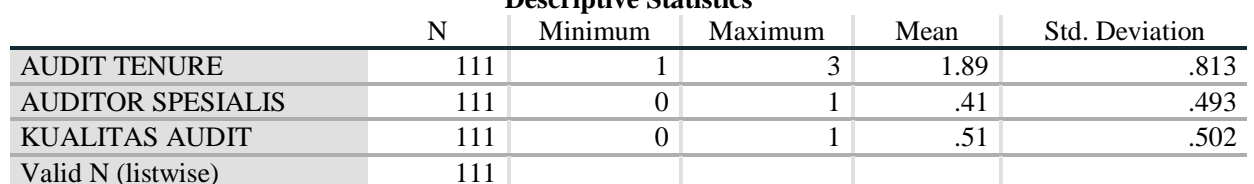

(Sumber : Output SPSS 26, 2020)

Berdasarkan tabel 4.3 diatas diketahui jumlah data yang diolah $(\mathrm{N})$ dalam pengujian ini adalah sebanyak 111 pengamatan yang diperoleh dari 37 perusahaan selama 3 tahun untuk semua variabel. Pada variabel audit tenure yang diukur dengan skala interval dengan menghitung jumlah tahun, memiliki nilai minimum sebesar 1 dan nilai maksimum adalah 3 serta rata-ratanya adalah 1.89 dengan standar deviasi 0.813 . Pengamatan untuk variabel auditor spesialis yang diukur dengan variabel dummy, memiliki nilai minimum sebesar 0 dan nilai maksimum adalah 1 serta rata-ratanya adalah 0.41 dengan standar deviasi 0.493. Kemudian pengamatan untuk variabel kualitas audit yang diukur dengan variabel dummy, memiliki nilai minimum sebesar 0 dan nilai maksimum adalah 1 serta rata-ratanya adalah 0.51 dengan standar deviasi 0.502 .

\subsubsection{Uji Multikolonieritas}

Uji multikolonieritas dimaksudkan untuk mengetahui apakah variabel-variabel yang digunakan memiliki lebih dari satu hubungan linear (pengaruh). Uji multikolonieritas dalam penelitian ini dilihat berdasarkan tabel correlation matrik pada output SPSS. Berikut hasil multikolonieritas yaitu:

Tabel 4.4

Hasil Uji Multikolonieritas

Correlation Matrix

\begin{tabular}{llr|r|r} 
& & \multicolumn{1}{c}{ Constant } & \multicolumn{1}{c}{ Audit Tenure } & \multicolumn{1}{c}{ Auditor Spesialis } \\
\hline Step 1 & Constant & 1.000 & -.891 & -.332 \\
\cline { 2 - 5 } & AUDIT TENURE & -.891 & 1.000 & .079 \\
\cline { 2 - 5 } & AUDITOR SPESIALIS & -.332 & .079 & 1.000 \\
\hline
\end{tabular}

(Sumber: Output SPSS 26, 2020)

Hasil pengujian yang ditampilkan dalam tabel 4.4 menunjukan bahwa koefisien korelasi antara variable masing-masing sebesar -0.998 dan -0.332, dimana nilai tersebut cukup tinggi (umumnya diatas 0.90), sehingga hal ini menunjukan adanya indikasi multikolonieritas.

\subsubsection{Pengujian Hipotesa}

Pengujian hipotesa dalam penelitian ini dilakukan dengan menggunakan regresi logistik (logistic regression), dengan tingkat signifikan (a) 5\% dan alat bantu IBM SPSS Statistik versi 26. Tujuan pengujian hipotesa ini untuk menentukan jawaban teoritis yang terkandung dalam pernyataan hipotesis dan didukung oleh fakta yang dikumpulkan dalam proses pengujian data (Indriantoro dan Supomo, 2016).

\subsubsection{Menilai Kelayakan Model Regresi}

Langkah pertama yang dilakukan adalah menilai kelayakan model regresi, pengujian kelayakan model regresi ini dilakukan dengan menggunakan goodness of fit test yang diukur dengan nilai chi-square pada bagian bawah uji hosmer and lemeshow. Berdasarkan tampilan tabel hosmer and lemeshow pada tabel 4.5 diketahui besarnya nilai statistik yang ditunjukan oleh nilai chi-square adalah sebesar 0.010 dengan probabilitas signifikan 1.000 dimana $1.000>0,05$. Hal ini menunjukan bahwa model regresi yang digunakan dalam penelitian ini layak dipakai untuk analisis selanjutnya, karena tidak ada perbedaan klasifikasi yang diprediksi dan diklasifikasi yang diamati dan model penelitian dapat mempridiksi nilai observasinya.

\section{Tabel 4.5}

Hasil Uji Hosmer And Lemeshow Test

Hosmer and Lemeshow Test

\begin{tabular}{cc|c|c} 
Step & Chi-square & Df & Sig. \\
\hline 1 & .010 & 4 & 1.000 \\
\hline (Sumber: Output SPSS 26, 2020)
\end{tabular}

Badewin-Siti Hujaimah, Pengaruh Audit Tenure Dan Audit Spesialis Terhadap Kualitas Audit pada Perusahaan Manufaktur yang Terdaftar di Bursa Efek Indonesia Tahun 2016-2018 


\subsubsection{Menilai Keseluruhan Model (Overall Model Fit)}

Langkah selanjutnya adalah menguji keseluruhan model regresi (overall model fit). Tabel 4.6 menunjukan nilai -2 Log Likehood (-2LL) pada awal (Block Number $=0$ ), dimana model hanya memasukan konstanta dengan nilai -2 Lock Likehood (-2LL) pada akhir (Block Number=1), dimana model memasukan konstanta dan variabel bebas. Hasil pengujian dari-2 Lock Likehoood (-2LL) pada awal (Block Number $=0)$ adalah sebagai berikut:

Tabel 4.6

Hasil Uji Keseluruhan Model Tahan 1

Block 0 : Beginning Block

Iteration History ${ }^{\mathrm{a}, \mathrm{B}, \mathrm{C}}$

\begin{tabular}{lrr|r} 
Iteration & -2 Log likelihood & \multicolumn{2}{c}{$\begin{array}{c}\text { Coefficients } \\
\text { Constant }\end{array}$} \\
\hline Step 0 & 1 & 153.798 & .054 \\
\cline { 2 - 5 } & 2 & 153.798 & .054 \\
\hline
\end{tabular}

a. Constant is included in the model.

b. Initial -2 Log Likelihood: 153.798

c. Estimation terminated at iteration number 2 because

parameter estimates changed by less than .001 .

(Sumber :Output SPSS 26, 2020)

Berdasarkan tabel diatas dilihat bahwa -2 Log Likehood (-2LL) pada awal (Block Number $=0$ ), yaitu model hanya memasukan konstanta atau variabel dependen (kualitas audit) sebesar 153.798. Jika pengujian keseluruhan model diajukan dengan memasukan seluruh variabel independen (audit tenure dan auditor spesialis) kedalam model penelitian, maka nilai -2 Log Likehood (-2LL) akan mengalami perubahan sebagaimana tampak pada tabel 4.7 sebagai berikut:

Tabel 4.7

Hasil Uji Keseluruhan Model Tahan 2

\section{Block 1 : Beginning Block}

Iteration History $\mathbf{a}, \mathrm{b}, \mathbf{b}, \mathbf{d}$

\begin{tabular}{|c|c|c|c|c|c|}
\hline \multirow{2}{*}{\multicolumn{2}{|c|}{ Iteration }} & \multirow[b]{2}{*}{-2 Log likelihood } & \multicolumn{3}{|c|}{ Coefficients } \\
\hline & & & Constant & Audit Tenure & Auditor Spesialis \\
\hline \multirow[t]{4}{*}{ Step 1} & 1 & 126.959 & -1.115 & .206 & 1.921 \\
\hline & 2 & 126.604 & -1.265 & .264 & 2.150 \\
\hline & 3 & 126.603 & -1.273 & 267 & 2.162 \\
\hline & 4 & 126.603 & -1.273 & .267 & 2.162 \\
\hline
\end{tabular}

a. Method: Enter

b. Constant is included in the model.

c. Initial -2 Log Likelihood: 153.798

d. Estimation terminated at iteration number 4 because parameter estimates changed by less than .001 .

( Sumber : Output SPSS 26, 2020)

Berdasarkan tabel 4.7 dapat dilihat nilai -2 Log Likehood mengalami perubahan berupa pengurangan yakni nilai -2LL akhir pada iterasi ke 4 menunjukan angka sebesar 126.603 . Adanya penurunan nilai $-2 \log$ Likehood tersebut yakni dari nilai -2 Lig Likehood awal sebesar 153.798 menjadi nilai -2 Log Likehood akhir sebesar 126.603 maka hal ini menunjukan bahwa model yang dihipotesiskan fit dengan data.

\subsubsection{Koefisien Determinasi (Negalkerke $R$ Square)}

Koefisien determinasi digunakan untuk mengetahui seberapa besar variabilitas variabel independen yakni audit tenure dan auditor spesialis yang dapat dijelaskan oleh variabilitas variabel dependen yakni kualitas audit. Hasil uji koefisien determinasi dalam penelitian ini dapat dilihat pada tabel 4.8 sebagai berikut:

\section{Tabel 4.8}

\section{Hasil Uji Koefisien Determinasi}

Model Summary

\begin{tabular}{ll|l|l} 
Step & -2 Log likelihood & Cox \& Snell R Square & Nagelkerke R Square \\
\hline 1 & $126.603^{\mathrm{a}}$ & .217 & .290
\end{tabular}

a. Estimation terminated at iteration number 4 because parameter estimates changed by less than .001 .

(Sumber : Output SPSS 26, 2020)

Berdasarkan tabel 4.8 dapat diketahui bahwa nagelkerke $R$ square adalah 0.290 yang berarti variabilitas variabel dependen (kualitas audit) yang dapat dijelaskan oleh variabel independen yaitu audit tenure dan auditor spesialis adalah sebesar 0.29 atau $29 \%$ sedangkan sisanya $71 \%$ dijelaskan oleh variabel lainnya yang tidak dimasukan dalam model regresi dalam penelitian ini. 


\subsubsection{Matrik Klasifikasi}

Matrik klasifikasi menunjukan kekuatan prediksi dari model regresi untuk memprediksi kemungkinan variabel dependen yang dalam penelitian ini adalah penerimaan kualitas audit pada perusahaan manufaktur yang terdaftar di Bursa Efek Indonesia (BEI) tahun 2016 sampai 2018 yakni terlihat pada tabel 4.9 berikut:

Tabel 4.9

Hasil Uji Matrik Klasifikasi

Classification Table ${ }^{\mathrm{a}}$

\begin{tabular}{|c|c|c|c|c|c|}
\hline & \multirow[b]{3}{*}{ Observed } & & \multicolumn{3}{|c|}{ Predicted } \\
\hline & & & \multicolumn{2}{|c|}{ Kualitas Audit } & \multirow[b]{2}{*}{ Percentage Correct } \\
\hline & & & 0 & 1 & \\
\hline \multirow[t]{3}{*}{ Step 1} & \multirow[t]{2}{*}{ Kualitas Audit } & 0 & 45 & 9 & 83.3 \\
\hline & & 1 & 21 & 36 & 63.2 \\
\hline & \multicolumn{2}{|c|}{ Overall Percentage } & & & 73.0 \\
\hline
\end{tabular}

The cut value is 500

(Sumber : Output SPSS 26, 2020)

Berdasarkan tabel 4.9 dapat dilihat bahwa menurut prediksi, perusahaan manufaktur yang yang terdaftar di Bursa Efek Indonesia (BEI) tahun 2016 sampai 2018 yang menerima kualitas audit adalah sebanyak 9 sedangkan hasil observasi sesungguhnya menunjukan bahwa perusahaan yang menerima kualitas audit adalah sebanyak 9 perusahaan. Jadi ketepatan model ini adalah $9 / 9$ atau sebesar $0 \%$. Selain itu menurut prediksi perusahaan yang menerima kualitas audit adalah 9 perusaahaan, sedangkan observasinya menunjukan perusahaan yang menerima kualitas audit adalah sebanyak 36 perusahaan. Jadi ketepatan model ini adalah 9/36 atau $63.2 \%$ dengan ketepatan prediksi keseluruha model ini adalah $73 \%$.

\subsubsection{Model Regresi Yang Terbentuk}

Pengujian model regresi yang terbentuk ini dilakukan untuk menguji hipotesa dalam penelitian ini, diterima model uji ini merupakan uji satu sisi yang dengan cara membandingkan antara tingkat signifikan (sig) dengan tingkat kesalahan $(a)=5 \%$. Apabila sig $<a$ dapat dikatakan variabel independen berpengaruh signifikan pada variabel dependen.

Tabel 4.10

Hasil Uji Model Regresi Yang Terbentuk Variables in the Equation

$\mathrm{B}$

S.E. Wald

Df

Sig.

$\operatorname{Exp}(\mathrm{B})$

\begin{tabular}{|l|l|r|r|r|r|r|r|}
\hline Step $1^{\mathrm{a}}$ & Audit Tenure & .267 & .269 & .989 & 1 & .320 & 1.307 \\
\cline { 2 - 9 } & Auditor Spesialis & 2.162 & .460 & 22.076 & 1 & .000 & 8.690 \\
\cline { 2 - 8 } & Constant & -1.273 & .585 & 4.728 & 1 & .030 & .280 \\
\hline
\end{tabular}

a. Variable(s) entered on step 1: AUDIT TENURE, AUDITOR SPESIALIS.

(Sumber : Output SPSS 26, 2020)

Berdasrkan tabel 4.10 dapat dilihat bahwa tingkat signifikan pada variabel audit tenure adalah 0.320 dengan tingkat kesalahan alpha 0.05 dimana nilai ini lebih besar dari alpha 0.05 sehingga dapat disimpulkan bahwa variabel audit tenure dikatakan tidak berpengaruh terhadap kualitas audit. Sedangkan untuk variabel auditor spesialis memiliki tingkat signifikannya adalah 0.000 lebih kecil dari tingkat alpha 0.05 , sehingga dapat disimpulkan bahwa variabel auditor spesialis berpengaruh terhadap kualitas audit

\subsection{Pembahasan}

4.3.1 Audit tenure tidak berpengaruh terhadap kualitas audit pada perusahaan manufaktur yang terdaftar di Bursa Efek Indonesia.

Hasil penelitian ini menggunakan regresi logistik yang menunjukan bahwa variabel audit tenure tidak berpengaruh terhadadap kualitas audit. Hal ini dapat dilihat berdasarkan tingkat signifikan variabel pada uji koefisien regresi yang menunjukan nilai koefisien regresi sebesar 0.267 dengan nilai signifikan 0.320 diatas nilai alpha 0.05 (5\%) sehingga $\mathrm{H}_{1}$ ditolak atau audit tenure tidak berpengaruh terhadap kualitas audit pada perusahaan manufaktur yang terdaftar di Bursa Efek Indonesia.

\subsubsection{Auditor spesialis berpengaruh terhadap kualitas audit pada perusahaan manufaktur yang terdaftar di Bursa Efek Indonesia.}

Hasil penelitian ini menunjukan regresi logistik dimana hasilnya menunjukan bahwa variabel auditor spesialis berpengaruh terhadap kualitas audit. Hal ini dapat dilihat berdasarkan tingkat signifikan variabel pada uji koefisien regresi yang menunjukan nilai koefisien regresi sebesar 2.162 dengan signifikan sebesar 0.000 dibawah nilai alpha $0.05(5 \%)$ sehingga $\mathrm{H}_{2}$ diterima atau auditor spesialis berpengaruh terhadap kualitas audit pada perusahaan manufaktur yang terdaftar di Bursa Efek Indonesia. 
Hasil penelitian ini berbeda dengan penelitian Maharani (2014) yang menyatakan bahwa auditor spesialisasi tidak berpengaruh terhadap kualitas audit. Hal ini disebabkan karena kualitas audit yang dihasilkan oleh KAP the Big 4 spesialis, dan KAP the Big 4 non spesialis adalah sama. Sedangkan hasil penelitian yang peneliti lakukan sama dengan hasil dari penelitian Adip Azinudin Nizar (2017) yang menyatakan auditor spesialis berpengaruh terhadap kualitas audit. Hal ini berarti bahwa auditor spesialis maupun non spesialis mempunyai pengalaman yang tidak sama dalam memngungkapkan kondisi perusahan untuk memberikan hasil audit yang berkualitas.

\section{KESIMPULAN DAN SARAN}

\subsection{Kesimpulan}

Audit tenure dan auditor spesialis terhadaap kualitas audit pada perusahaan manufaktur yang terdaftar di Bursa Efek Indonesia, dengan jumlah sampel sebanyak 37 perusahaan data olahan sebanyak 111 data olahan priode 2016-2018. Berdasarkan rumusan masalah, tujuan penelitian, landasan teori, hipotesa dan hasil penelitian yang dilakukan maka dapat disimpulkan sebagai berikut :

1. Hasil penelitian yang menunjukan nilai signifikan 0.320 diatas nilai alpha 0.05 (5\%) membuktikan bahwa variabel audit tenure tidak berpengaruh terhadap kualitas audit. Hal ini karena masa perikatan yang singkat dapat membuat seorang auditor tidak terlalu memahami karakteristik perusahaan kliennya sehingga dapat menyebabkan kualitas audit yang dihasilkan rendah. Sedangkan masa perikatan yang panjang dapat membuat auditor lebih memahami karakteristik bisnis dari kliennya seiring dengan bertambahnya jumlah Tenure yang dilakukan dan tidak melebihi jangka waktu yang telah ditetapkan oleh pemerintah. Audit Tenure ini sering dikaitkan dengan independensi yang harus selalu dijaga oleh auditor. Hasil penelitian menunjukan bahwa nilai signifikan 0.000 dibawah nilai alpha 0.05 (5\%) membuktikan bahwa variabel auditor spesialis berpengaruh terhadap kualitas audit. Auditor spesialis maupun nonspesialis mempunyai pengalaman yang sama dalam mengungkapkan kondisi perusahan untuk memberikan hasil audit yang berkualitas.

2. Variabelitas kualitas audit yang dapat dijelaskan oleh variabel audit tenure dan auditor spesialis adalah sebesar $29 \%$ sedangkan sisanya adalah $71 \%$ dijelaskan oleh variabel lainnya diluar model penelitian.

\subsection{Saran}

Untuk keperluan penelitian di masa mendatang, agar diperoleh hasil yang lebih dan akurat, perlu diperhatikan saran-saran sebagai berikut:

1. Bagi peneliti selanjutnya diharapkan dapat menambah variabel-variabel lain yang dapat mempengaruhi kualitas audit. Rendahnya nilai $\mathrm{R}^{2}$ dari model yang diuji dalam penelitian ini meunjukkan bahwa variabel lain yang tidak digunakan dalam penelitian ini mempunyai pengaruh yang lebih besar terhadap kualitas audit

2. Peneliti selanjutnya, diharapkan dapat memperluas objek penelitian dan menambah populasi dan tidak terbatas hanya perusahaan manufaktur

\section{DAFTAR PUSTAKA}

Arens et all. 2008. Auditing and Assurance Servyces-An Intergrated Approach. Prentice Hall.

Farida, I. 2016. Pengaruuh Independensi, Kompetensi, Due Professional Care, dan ETika Terhadap Kualitas Audit (Studi Empiris pada KAP di Kota Malang). Journal Riset Mahasiswa

Ghozali, Imam. 2011. AplikasiAnalisis Multivariate dengan Program SPSS. Semarang :BP Universitas Diponogoro

Hery. 2017. Auditing \& Asurans. Pemeriksaan Akuntansi Berbasis Standar Internasional. Gramedia: Jakarta

Ikatan Akuntan Indonesia, 2001. Standar Profesionalisme Akuntan Publik. Salemba Empat. Jakarta.

Indriantoro, Supomo. 2016. Metodologi Penelitian Bisnis. Edisi Keenam. Fakultas Ekonomika dan UGM.

Junaidi, dan Jogiyanto Hartono. 2010. Faktor Non Keuangan Pada Opini Going Concern. Jurnal SNA III, Simposium Nasional Akuntansi III Purwokerto 2010. 1-23

Kurniasih, Margi dan Abdul Rohman. 2014. Pengaruh Audit Fee Audit, Audit Tenure, dan Rotasi Audit Terhadap Kualitas Audit. Diponegoro Journal Of Accounting Volume 3, Nomor 3

Maharani, Putri Adisti, 2014. Pengaruh Audit Tenure, Audit Fee, Rotasi Audit Dan Spesialisasi Auditor Terhadap Kualitas Audit. Universitas Muhammadiyah Surakarta

Mulyadi .2014. Auditing Buku 1 Edisi keenam Cetakan Kesembilan. Salemba Empat: Jakarta.

Nizar, Adip Azinudin. 2017. Pengaruh Rotasi, Reputasi Dan Spesialis Auditor Terhadap Kualitas Audit (studi empiris pada perusahaan manufaktur listed di BEI). KOMPARTEMEN, Vol. 15 No.2

Panjaitan. Clinton Marshal, dkk. 2014. Pengaruh Tenure Ukuran KAP Dan Spesialisai Auditor Terhadap Kualitas Audit.E-Jurnal volume 3. No3.

Pramaswaradana, I Gusti Ngurah Indra dan Astika, Ida Bagus Putra. 2017. Pengaruh audit tenure, audit fee, rotasi auditor, spesialisasi auditor dan umur publikasi pada kualitas audit. E-Jurnal Akuntansi Universitas Udayana. Vol. 19.1

Badewin-Siti Hujaimah, Pengaruh Audit Tenure Dan Audit Spesialis Terhadap Kualitas Audit pada Perusahaan Manufaktur yang Terdaftar di Bursa Efek Indonesia Tahun 2016-2018 
www.statistikolahdata.com. 2020

https://www.kompasiana.com/dindachristie/audit-terhadap-siklus-pengeluaran 